DOI : https://doi.org/10.24843/JFU.2020.v09.i03.p03

pISSN: 2301-7716; eISSN: 2622-4607

Jurnal Farmasi Udayana, Spesial Issue Desember 2020, 152-159

\title{
Hubungan Pemberian Ekstrak Cordyline fruticosa L.A Cheval Terhadap Penurunan Kolesterol Tikus Putih
}

\author{
Dian Rahmawati ${ }^{*}$, Joni Tandi², Riry Mukhliza ${ }^{2}$

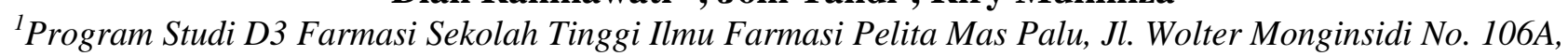 \\ Palu, Indonesia, 94111 \\ ${ }^{2}$ Program Studi S1 Farmasi Sekolah Tinggi Ilmu Farmasi Pelita Mas Palu, Jl. Wolter Monginsidi No. 106A, \\ Palu, Indonesia, 94111 \\ *Corresponding author e-mail: dianrahmawati.nf@gmail.com
}

Riwayat artikel: Dikirim: 15/10/2020; Diterima: 10/11/2020, Diterbitkan: 15/12/2020

\begin{abstract}
This study aims to determine the effect of ethanol extract of cordyline fruticose leaves in reducing total cholesterol levels of male white rats. This study used 30 male white rats which were divided into 6 treatment groups, each groups consistent of 5 test animals. Group I was normal control, group II was negative control (High cholesterol died and streptozotocin $30 \mathrm{mg} / \mathrm{kgBW}$, group III was positive control (Simvastatin suspension), group IV, V, VI were each given an ethanol extract of cordyline fruticose leaves at a dose of 100 $\mathrm{mg} / \mathrm{kg} \mathrm{BW}, 150 \mathrm{mg} / \mathrm{kg} \mathrm{BW}$ and $200 \mathrm{mg} / \mathrm{kg} \mathrm{BW}$ for 14 consecutive days. Measurements of analyzed using a one-way statistical test (ANOVA) at 95\% confidence level and continued with the Least Significant Difference (LSD) test to analyze differences between the groups. The result showed that the ethanol extract of cordyline fruticose leaves at a dose $200 \mathrm{mg} / \mathrm{kgBW}$ was able to reduce total cholesterol levels in white rats with cholesterol level of $39 \mathrm{mg} / \mathrm{dL}$.
\end{abstract}

Keywords: High fat feed, Cordyline fruticosa, Cholesterol.

\begin{abstract}
ABSTRAK
Penelitian ini bertujuan untuk mengetahui efek ekstrak etanol daun andong dengan kontrol normal dalam menurunkan kadar kolesterol total tikus putih jantan. Penelitian ini menggunakan hewan uji tikus putih jantan sebanyak 30 ekor yang dibagi menjadi 6 kelompok perlakuan, tiap kelompok terdiri dari 5 ekor hewan uji. Kelompok I kontrol normal, Kelompok II kontrol negatif (pakan tinggi kolesterol dan streptozotocin 30 $\mathrm{mg} / \mathrm{kgBB}$ ), Kelompok III kontrol positif (suspensi simvastatin), Kelompok IV, V, VI masing-masing diberikan ekstrak etanol daun andong dosis $100 \mathrm{mg} / \mathrm{kgBB}$, dosis $150 \mathrm{mg} / \mathrm{kgBB}$, dan dosis $200 \mathrm{mg} / \mathrm{kgBB}$ secara peroral selama 14 hari berturut-turut. Pengukuran Kadar kolesterol total pada hari ke 0, 14, 21, 28, 35. Data yang diperoleh dianalisis menggunakan uji statistik one way (ANOVA) pada taraf kepercayaan $95 \%$ dan dilanjutkan dengan uji Least Significant Difference (LSD) untuk melihat perbedaan antar perlakuan. Berdasarkan hasil penelitian menunjukkan bahwa Ekstrak etanol daun andong dosis $300 \mathrm{mg} / \mathrm{kgBB}$ mampu menurunkan kadar kolesterol total pada tikus putih dengan kadar kolesterol $39 \mathrm{mg} / \mathrm{dL}$.
\end{abstract}

Kata kunci: Cordyline fruticosa L.A Cheval, Daun Andong, Kolesterol.

\section{PENDAHULUAN}

Menurut staistik dunia ada 9,4 juta kematian setiap tahun yang disebebkan oleh penyakit kardiovaskuler dan $45 \%$ disebabkan oleh jantung koroner, diperkirakan angka tersebut akan meningkat hingga 23,3\% pada tahun 2030 (Marbun, 2019), dan pada tahun 2018 (Riskesdas 2018) penderita dislipidemia mencapai $66,91 \%$. Tingginya angka kejadian 
DOI : https://doi.org/10.24843/JFU.2020.v09.i03.p03

pISSN: 2301-7716; eISSN: 2622-4607

Jurnal Farmasi Udayana, Spesial Issue Desember 2020, 152-159

tersebut disebabkan oleh perubahan gaya hidup masyarakat, pola makan, faktor lingkungan yang kurang baik, kurangnya aktivitas fisik seperti olahraga dan faktor stres (Waloya et al., 2013). Konsumsi makanan yang berlemak, makanan cepat saji (fast food), dan kurang berolahraga merupakan kebiasaan buruk masyarakat yang dapat menimbulkan berbagai penyakit yang berkaitan dengan metabolisme salah satuya kolesterol (Ranti et al., 2013).

Penggunaan alternativ tanaman sebagai obat tradisional salah satunya adalah Andong (Cordyline fruticosa L.A Cheval) yang merupakan tanaman obat yang banyak tumbuh di sekitar masyarakat. Tanaman andong biasanya ditanam sebagai tanaman hias dipekarangan rumah, tanaman pagar atau pembatas perkebunan teh karena warnanya yang mencolok. Tanaman andong memiliki beberapa kandungan senyawa aktif yang terdapat pada tanaman andong antara lain saponin, tanin, flavonoid, dan polivenol (Widiyantoro \& Destiarti, 2018). Secara tradisional tanaman andong juga digunakan sebagaiobat antiinflamasi. Tanaman andong memiliki kandungan senyawa saponin yang memiliki aktivitas dalam menurunkan kadar kolesterol (N. W. Bogoriani et al., 20 15).

Penelitian sebelumnya tentang penurunan kadar plasma kolesterol daun andong (Cordyline terminalis Kunth) yang telah dilakukan oleh N. W. Bogoriani menggunakan dosis $30 \mathrm{mg} / \mathrm{hari}$. Dari hasil penelitian tersebut dapat diperoleh hasil yang menyatakan bahwa tanaman andong memiliki kandungan senyawa saponin dimana senyawa tersebut dapat menurunkan kadar kolesterol total, LDL kolesterol, Trigliserida, total asam empedu, meningkatkan kadar kolesterol HDL (Bogoriani et al., 2015).

Berdasarkanlatar belakang maka dilakukan penelitian ekstrak etanol daun andong (Cordyline fruticosa L. A Cheval) terhadap penurunan kadar kolesterol total tikus putih jantan (Rattus norvegicus) yang dibandingkan dengan kontrol normal dan mengetahui dosis efektifnya (100 mg/kgBB, $150 \mathrm{mg} / \mathrm{kgBB}, 200$ $\mathrm{mg} / \mathrm{kgBB}$ ) dalam menurukan kadar kolesterol total dari tikus putih jantan yang diinduksi dengan pakan tinggi lemak dan streptozotocin.

\section{BAHAN DAN METODE}

\subsection{Alat}

Alat-alat gelas, ayakan nomor 40 mesh, bejana maserasi, blender, botol minun tikus, kandang hewan uji, pipet mikro,rotary vaccum evaporator, sentrifuge, spektrofotometri Uv visible,spuit injeksi, tabung reaksi, spuit oral, tempat makan tikus, timbangan analitik, timbangan gram dan Waterbath.

\subsection{Bahan}

Air suling, asam klorida, besi (III) klorida, Citrate-buffer salin (asam sitrat dan natrium sitrat), kulit buah petai, dragendrof, etanol absolut 96\%, handskun(sensi), kapas, kertas label, kertas saring, lakban, masker, serbuk magnesium, Na CMC, natrium hidroksida, kloroform, natrium klorida, pakan standar, pakan tinggi propltiurasil, reagen enzime,simvastatin.

\subsection{Pembuatan Ekstrak Etanol Daun Andong}

Pembuatan ekstrak etanol daun andong dilakukan dengan metode maserasi menggunakan pelarut etanol 96\%. Serbuk simplisia ditimbang sebanyak 1000 gram lalu dimasukkan kedalam bejana maserasi dengan menggunakan pelarut etanol sebanyak $6 \mathrm{~L}$, ditutup lalu dibiarkan selama $3 \times 24$ jam terlindung dari cahaya sambil sesekali diaduk. Bejana yang digunakan adalah 3 bejana maserasi.Maserat yang diperoleh selanjutnya dievaporasi atau memisahkan larutan menggunakan Rotary Vaccum Evaporator pada suhu $40^{\circ} \mathrm{C}$ dan dilanjutkan dengan pengentalan yang dilakukan dengan menggunakan waterbath 
DOI : https://doi.org/10.24843/JFU.2020.v09.i03.p03

pISSN: 2301-7716; eISSN: 2622-4607

Jurnal Farmasi Udayana, Spesial Issue Desember 2020, 152-159

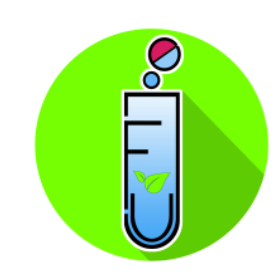

dengan suhu $60^{\circ} \mathrm{C}$ hingga diperoleh ekstrak kental.

\subsection{Pembuatan Suspensi Simvastatin}

Tablet simvastatin $10 \mathrm{mg}$ digerus, kemudian ditimbang setara dengan 1,8 mg lalu masukkan kedalam lumpang dengan menambahkan suspensi Na CMC 0,5\% sedikit demi sedikit sambil digerus hingga homogen. Memasukan kedalam labu takar $25 \mathrm{ml}$, kemudian dicukupkan dengan suspensi $\mathrm{Na}$ CMC 0,5\%.

\subsection{Pembuatan Pakan Tinggi Kolesterol}

Pakan tinggi kolesterol yang digunakan adalah lemak babi, dan kuning telur puyuh . Pakan dibuat dengan cara sebagai berikut: melelehkan lemak babi dengan cara memanaskan hingga lemak babi menjadi minyak. Telur dipisahkan kuning dan putih telur, diambil kuningnya dan campurkan dengan minyak babi sampai homogen, diberikan selama 14 hari secara per oral.

\subsection{Analisis Data}

Data yang diperoleh berupa kadar kolesterol dianalisis secara statistik

$\begin{array}{lr}\text { menggunakan analisis } & \text { Anova } \\ \text { (One Way Anova) pada taraf kepercayan } & 95 \%, \\ \text { selanjutnya dilakukan uji Post hoc (LSD) untuk } \\ \text { mengetahui perbedaan } & \text { yang } \\ \text { bermakna antara perlakuan. } & \end{array}$

\section{HASIL}

Uji pendahuluan atau uji penapisan fitokimia bertujuan untuk memastikan adanya kandungan senyawa metabolit sekunder pada sampel Daun Andong yang digunakan dan bertujuan untuk memastikan apakah cara ekstraksi yang digunkan sudah benar. Hasil dari uji penapisan fitokimia diperoleh bahwa sampel andong memiliki kandungan metabolit sekunder yaitu alkaloid, flavonoid, saponin dan tanin yang dapat dilihat pada Tabel 3.1.Hal ini ini sejalan dengan penelitian Widiyantoro \& Destiarti (2018) bahwa ekstrak etanol Daun Andong positif mengandung senyawa metabolit sekunder yaitu alkaloid, flavonoid, saponin dan tanin. Hasil uji penapisan fitokima dapat dilihat pada tabel berkut :

Tabel 1. Hasil Uji Penapisan Fitokimia Ekstrak Etanol Daun Andong

\begin{tabular}{|c|c|c|c|}
\hline \multirow{2}{*}{$\begin{array}{c}\text { Senyawa } \\
\text { Metabolit } \\
\text { Sekunder } \\
\end{array}$} & \multirow[t]{2}{*}{ Pereaksi } & \multicolumn{2}{|l|}{ Hasil } \\
\hline & & Ekstrak Daun Andong & Ket \\
\hline Flavonoid & Magnesium dan $\mathrm{HCl}$ & Terbentuknya warna merah bata & + \\
\hline Saponin & Tespembentukanbusa & $\begin{array}{l}\text { Adanya busa setinggi } \pm 1 \mathrm{~cm} \text { dan tetap stabil } \\
\text { selama } 5 \text { menit setelah dilakukan pengocokan } \\
\text { yang kuat }\end{array}$ & + \\
\hline Alkaloid & Pereaksi dragendorf & Terbentuknya endapan merah & + \\
\hline Tanin & Penambahan $\mathrm{FeCl} 3$ & Terbentuk warna hijau kehitaman & + \\
\hline
\end{tabular}

Tikus dibuat dalam keadaan Hiperkolesterolemia-Diabetes dengan cara diberikan Pakan Tinggi Lemak dan PTU (Propitiourasil) selama 14 hari sebelum diinduksi Streptozotocin. Pemberian PTU bersama dengan Pakan Tinggi Lemak yang bertujuan untuk meningkatkan kadar kolesterol total pada tikus putih jantan yang dimana pemberian PTU menurut penelitian Rahma et al., (2014) dapat meningkatkan kadar kolesterol total dengan mekanisme kerja yaitu menghambat sintesis hormone tiroid. Menurut Ofli et al., (2013), streptozotocin sering digunakan sebagai induksi diabetes 
DOI : https://doi.org/10.24843/JFU.2020.v09.i03.p03

pISSN: 2301-7716; eISSN: 2622-4607

Jurnal Farmasi Udayana, Spesial Issue Desember 2020, 152-159

mellitus pada hewan uji karena selektif merusak sel beta pankreas. Adapun hubungan kolesterol dengan diabetes yaitu pada penderita diabetes akan mengalami resistensi insulin dimana resistensi insulin adalah suatu kondisi yang berhubungan dengan kegagalan organ sebagai aktivitas respon target normal hormon insulin.

Penelitian diawali dengan pengukuran kadar kolesterol normal tikus pada hari ke-0 sebelum pemberian Pakan Tinggi Lemak, PTU, STZ dan Perlakuan ekstrak dosis 100, 150 dan $200 \mathrm{mg} / \mathrm{kgBB}$. rata-rata kadar kolesterol tikus putih jantan pada kelompok kontrol normal, kontrol positif, kontrol negatif dan kelompok perlakuan ekstrak Daun Andong dosis 100, 150 dan $200 \mathrm{mg} / \mathrm{kgBB}$ tidak berbeda signifikan dimana nilai signifikasinya yaitu 0,069 ( $p>0,05)$. Pada hari ke-14 dilakukan pemberian pakan tinggi lemak dan PTU pada kelompok tikus, dimana pemberian Pakan Tinggi Lemak dapat meningkatkan kadar kolesterol karena mengandung 2138,17mg/100g kolesterol pada kuning telur puyuh dan pada pemberian PTU dapat meningkatkan kadar kolesterol dengan cara meningkatkan kadar plasma LDL yang turut dapat meningkatkan kadar kolesterol total (Kenta et al., 2018). Pada hari ke-21 dilakukan pemberian induksi Streptozotocin. Peningkatan kadar kolesterol setelah pemberian induksi Streptozotocin dibandingkan pemberian Pakan Tinggi Lemak dan PTU. Hal ini menunjukkan bahwa induksi Streptozotocin dapat merusak sel beta pankreas secara signifikan sehingga terjadi resistensi insulin yang mengakibatkan peningkatan kadar kolesterol pada tikus (Ayu et al., 2017). Berdasarkan hasil penelitian pada hari ke 14 sampai hari ke 21 setelah diberikan induksi Streptozotocin pada semua kelompok uji. Berdasarkan hasil penelitian pada kadar kolesterol dengan nilai tertinggi diperoleh oleh kelompok kontrol negatif yaitu $220 \mathrm{mg} / \mathrm{dL}$ dan kadar kolesterol terendah diperoleh oleh kelompok kontrol normal yaitu $34 \mathrm{mg} / \mathrm{dL}$. Data hasil uji statistik kadar kolesterol kelompok kontrol normal berbeda signifikan dengan semua kelompok perlakuan ( $p=$ 0,000). Rata-rata kadar kolesterol dapat dilihat pada tabel berikut:

Tabel 2. Rerata LSD Kadar Koleterol Total

\begin{tabular}{|c|c|c|c|c|c|c|}
\hline \multicolumn{7}{|c|}{ Rerata \pm SD Kadar Kolesterol Total Darah(mg/dL) } \\
\hline Hari & K. Sehat & K. Negatif & K. Positif & $\begin{array}{c}\text { Ekstrak } 100 \\
\text { mg }\end{array}$ & Ekstrak $150 \mathrm{mg}$ & $\begin{array}{l}\text { Ekstrak 200 } \\
\text { mg }\end{array}$ \\
\hline $\mathbf{0}$ & $38 \pm 9,25^{\mathrm{a}}$ & $42 \pm 3^{\mathrm{a}}$ & $35 \pm 7.28^{\mathrm{a}}$ & $46 \pm 5.70^{\mathrm{a}}$ & $45 \pm 4.14^{\mathrm{a}}$ & $44 \pm 6^{\mathrm{a}}$ \\
\hline 14 & $35 \pm 9.39^{\mathrm{b}}$ & $203 \pm 15.64^{\mathrm{a}}$ & $194 \pm 19.59^{\mathrm{a}}$ & $177 \pm 39.30^{\mathrm{a}}$ & $182 \pm 21,51^{\mathrm{a}}$ & $204 \pm 17.85^{\mathrm{a}}$ \\
\hline 21 & $34 \pm 6.94^{b}$ & $220 \pm 7,90^{\mathrm{a}}$ & $218 \pm 15.24^{\mathrm{a}}$ & $206 \pm 11,93^{\text {a }}$ & $208 \pm 5.95^{\mathrm{a}}$ & $213 \pm 10.42^{\text {a }}$ \\
\hline 28 & $35 \pm 5$ & $214 \pm 25.39^{\mathrm{a}}$ & $140 \pm 7.89^{b}$ & $156 \pm 13.92^{b}$ & $124 \pm 11.30^{\mathrm{b}}$ & $117 \pm 8.2^{\mathrm{b}}$ \\
\hline 35 & $38 \pm 6.78^{c}$ & $239 \pm 9.78^{\mathrm{a}}$ & $35 \pm 6.90^{c}$ & $65 \pm 24^{\mathrm{b}}$ & $60 \pm 11.19^{\mathrm{b}}$ & $39 \pm 4.18^{c}$ \\
\hline
\end{tabular}


DOI : https://doi.org/10.24843/JFU.2020.v09.i03.p03

pISSN: 2301-7716; eISSN: 2622-4607

Jurnal Farmasi Udayana, Spesial Issue Desember 2020, 152-159

Pada hari ke-28 dilakukan pemberian ekstrak Daun Andong selama 7 hari pada semua kelompok uji. Berdasarkan hasil uji statistik memperlihatkan hasil kelompok kontrol positif dan kelompok perlakuan ekstrak dosis 100, 150 dan $200 \mathrm{mg} / \mathrm{kgBB}$ berbeda signifikan dengan kelompok kontrol negative $(p=0,005)$. Hal ini menunjukkan bahwa pemberian ekstra dosis 150 dan $200 \mathrm{mg} / \mathrm{kgBB}$ telah mampu menurunkan kadar kolesterol total dibandingkan dengan kontrol positif (Simvastatin) akan tatapi pemberian ekstrak etanol daun andong selama 7 hari belum mampu menurunkan kadar kolesterol total pada hewan uji hingga mendekati kadar normal. Pada hari ke-35 dilakukan pemberian ekstrak selama 14 hari pada semua kelompok uji. Berdasarkan hasil penelitian kadar kolesterol tertinggi diperoleh pada kelompok perlakuan dosis $100 \mathrm{mg} / \mathrm{kgBB}$ yaitu $65 \mathrm{mg} / \mathrm{dL} \mathrm{mg} / \mathrm{dL}$ dan kadar kolesterol terendah diperoleh pada kelompok perlakuan dosis $200 \mathrm{mg} / \mathrm{kgBB}$ kontrol positif yaitu $39 \mathrm{mg} / \mathrm{dL}$. Berdasarkan hasil uji statistik kelompok kontrol normal, kontrol positif dan kelompok perlakuan dosis $200 \mathrm{mg} / \mathrm{kgBB}$ tidak berbeda signifikan $(p=0,780)$. Hal ini menunjukan bahwa pemberian suspensi simvatsatin dan ekstrak etanol daun andong telah mempu menurunkan kadar kolesterol hingga mecapai kadar normal kolesterol. dosis 200 $\mathrm{mg} / \mathrm{kgBB}$ merupakan dosis yang efektif dalam menurunkan kadar kolesterol total tikus putih jantan. Pemberian suspensi Simvastatin mampu menurunkan kadar kolesterol total yang sudah mendekati kadar normal dimana simvastatin merupakan golongan obat Penghambat HMG Co-A dengan inhibisi kompetitif yang paling efektif untuk menurunkan kadar kolesterol (Putri et al., 2018). Penurunan kadar kolesterol total dapat dilihat pada Gambar Grafik berikut:

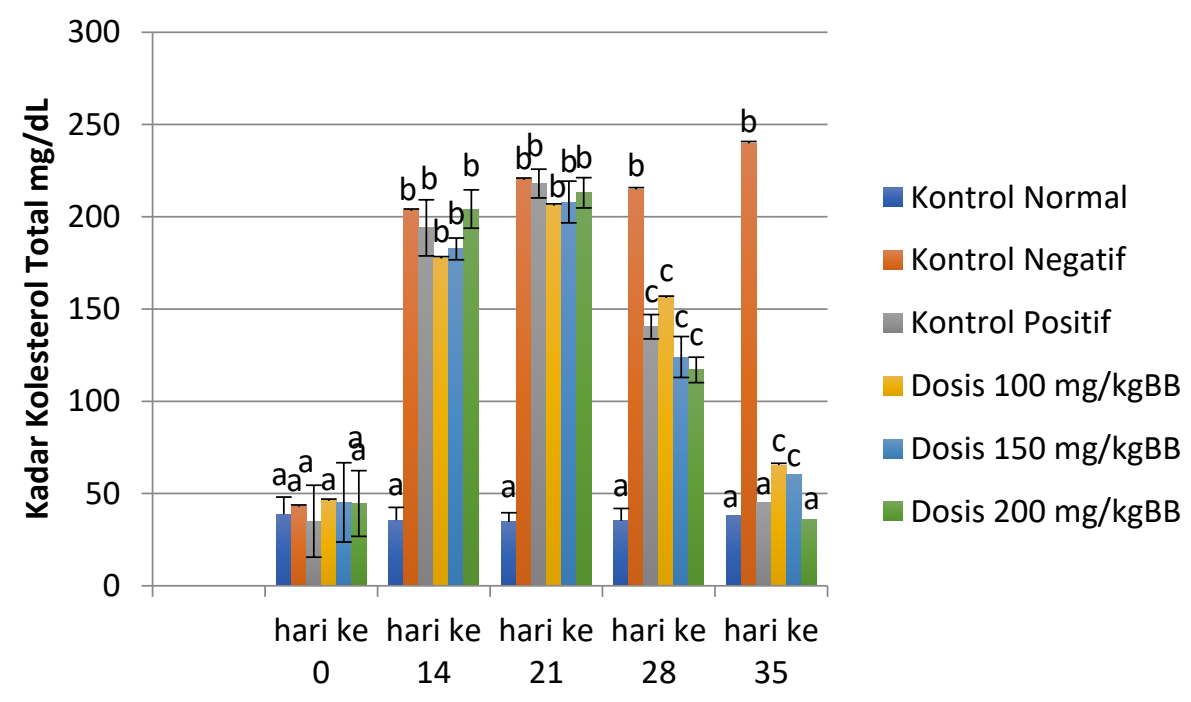

Gambar 1. Grafik Hasil Pengukuran Kadar 
DOI : https://doi.org/10.24843/JFU.2020.v09.i03.p03

pISSN: 2301-7716; eISSN: 2622-4607

Jurnal Farmasi Udayana, Spesial Issue Desember 2020, 152-159
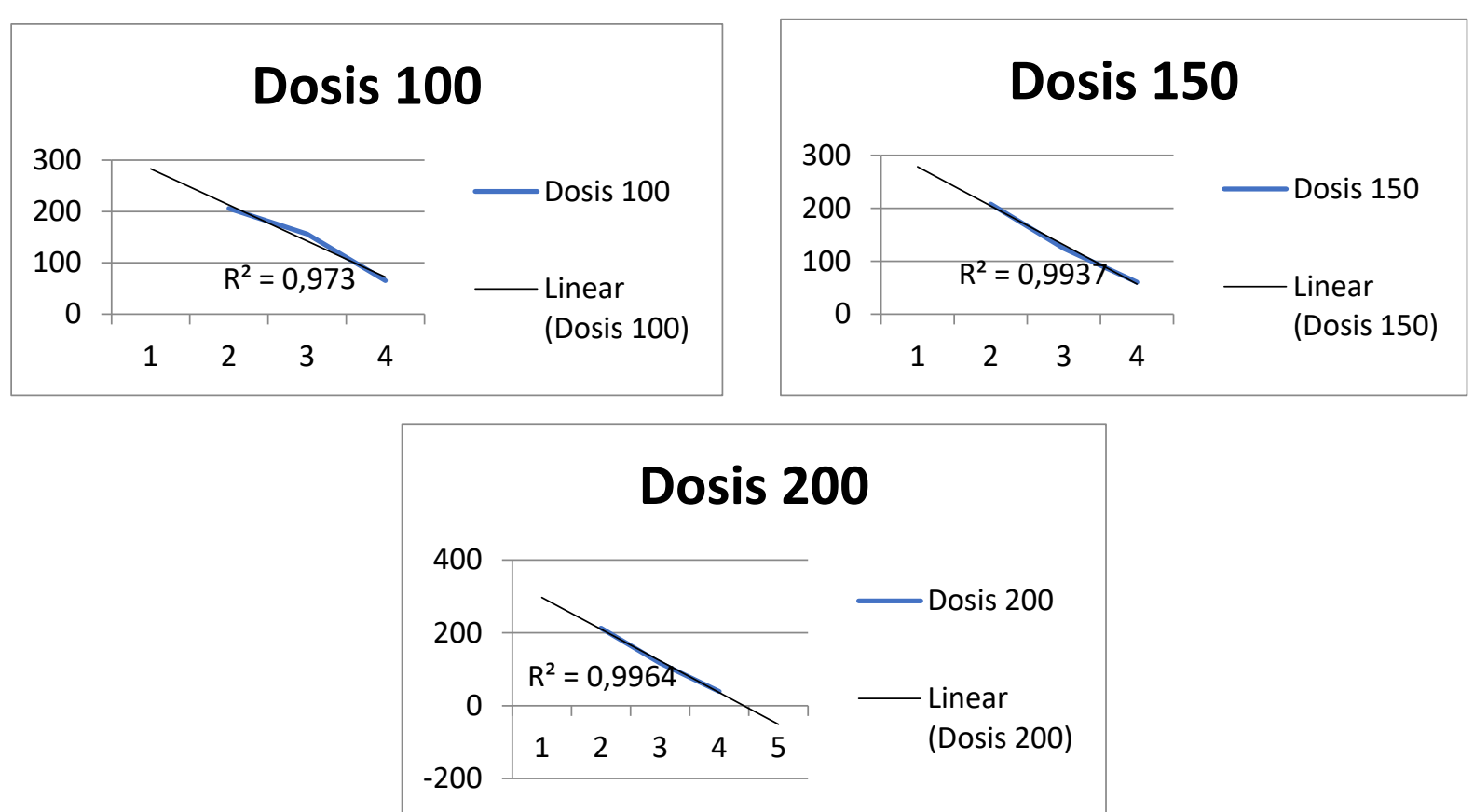

Gambar 2. Grafik Hasil Pengukuran Kadar Kolesterol

Berdasarkan pada Gambar 2. Grafik garis dosis $100 \mathrm{mg} / \mathrm{dL}$ dapat dilihat garis penurunan kadar kolesterol dengan nilai $R^{2}=0,973$ sedangkan pada Gambar 4.3 grafik garis dosis $150 \mathrm{mg} / \mathrm{dL}$ dengan nilai $\mathrm{R}^{2}=0,993$, dan pada Gambar grafik garis dosis $200 \mathrm{mg} / \mathrm{dL}$ dengan nilai $\mathrm{R}^{2}=0,996$. Berdasarkan data grafik tersebut dapat diketahui bahwa dosis $200 \mathrm{mg} / \mathrm{kgBB}$ merupakan dosis yang efektif dalam menurunkan kadar kolesterol total dengan nilai $\mathrm{R}^{2}$ yang hampir mencapai angka $1\left(\mathrm{R}^{2}=0,996\right)$. Hal ini sesuai dengan teori yang menyatakan bahwa semakin mendekati nilai $\mathrm{R}^{2}$ dengan angka 1 maka semakin baik model persamaan yang menjelaskan adanya korelasi dengan aktivitas yang sebenarnya (Muchtaridi et al., 2018).

\section{PEMBAHASAN}

Saponin menghambat penyerapan kolesterol dan asam empedu di usus kecil.Kolesterol dan asam empedu disekresikan oleh hati untuk meningkatkan pencernaan dan penyerapan lipid. Eskresi kolesterol dan asam empedu yang meningkat melalui feses menyebabkan terjadi penurunan kadar kolesterol.Tanin bersifat sebagai astringen dengan kemampuan mengendapkan mukosa protein yang ada didalam permukaan usus halus. Proses penyerapan makanan menjadi berkurang, sehingga penyerapan lemak maupun kolesterol didalam saluran pencernaan dapat dihambat (Afrilliani et al., 2014).

Tanin bersifat sebagai astringen dengan kemampuan mengendapkan mukosa protein yang ada didalam permukaan usus halus. Proses penyerapan makanan menjadi berkurang, sehingga penyerapan lemak maupun kolesterol didalam saluran pencernaan dapat dihambat (Afrilliani et al., 2014).

Flavonoid dalam menurunkan kadar trigliserida yaitu dengan cara meningkatnya kerja aktivitas enzim lipoprotein lipase yang 
DOI : https://doi.org/10.24843/JFU.2020.v09.i03.p03

pISSN: 2301-7716; eISSN: 2622-4607

Jurnal Farmasi Udayana, Spesial Issue Desember 2020, 152-159

berfungsi dalam mengendalikan kadar trigliserida. Alkaloid dalam menurunkan kadar kolesterol yaitu penghambatan aktivitas enzim lipase pankreas sehingga meningkatkan sekresi lemak melalui feses, akibatnya penyerapan lemak oleh hati terhambat sehingga tidak diubah menjadi kolesterol (Widayanti et al., 2016).

\section{KESIMPULAN}

Berdasarkan hasil penelitian dan pembahasan maka dapat disimpulkan bahwa :

1. Ekstrak etanol daun andong (Cordyline fruticosa L.A Cheval) mengandung senyawa metabolit sekunder yaitu alkaloid, flavonoid, saponin dan tanin.

2. Ekstrak etanol daun andong (Cordyline fruticosa L.A Cheval) pada dosis bertingkat memiliki efek terhadap penurunan kadar kolesterol total terhadap tikus putih jantan (Rattus norvegicus)

3. Ekstrak etanol daun andong dosis $200 \mathrm{mg} / \mathrm{kg}$ BB merupakan dosis yang efektif untuk menurunkan kadar kolesterol total.

\section{UCAPAN TERIMAKASIH}

Terima kasih kepada rekan-rekan peneliti bapak Dr. apt. Joni Tandi, M. Kes dan Riry Mukhliza, S.Farm yang telah bekerja sama dalam penelitian ini.

\section{DAFTAR PUSTAKA}

1. Afrilliani, D. A., Supriyanta, B., Rahayu, M., Analis, J., Poltekkes, K., Yogyakarta, K., ... Group, C. (2014). Pengaruh Pemberian Rebusan Daun Salam (Eugenia polyantha Wight.) Terhadap Kadar Kolesterol Low Density Lipoprotein (LDL) Serum Tikus Putih (Rattus norvegicus) Hiperkolesterolemia. JURNAL TEKNOLOGI LABORATORIUM, 3.

2. Ayu, G., Tandi, J., \& Nobertson, R. (2017). UJI EFEK EKSTRAK ETANOL DAUN KENIKIR ( Cosmos caudatus Kunth .) TERHADAP PENURUNAN KADAR
KOLESTEROL PADA TIKUS WISTAR ( Rattus norvegicus ) DIABETES. Farmakologika Jurnal Farmasi, XIV(2).

3. Bogoriani, N. W., Putra-Manuaba, I. B., Suastika, K., \& Wita, I. W. (2015). of Biomedical Pharmaceutical sciences PLASMA CHOLESTEROL AND BILE ACIDS LEVELS BY INCREASED THE EXCRETION OF FECAL TOTAL BILE ACIDS AND. European Journal of Biomedical and Pharmaceutical Sciences, 2(5), 122-134.

4. Kenta, Y. S., Tandi, J., T, B. L., \& T, D. (2018). UJI EKSTRAK DAUN UBI JALAR UNGU (Ipomoea batatas) TERHADAP PENURUNAN KADAR KOLESTEROL TIKUS PUTIH. Farmakologika Farmasi Jurnal, XV(1).

5. Marbun, R. L. (2019). Potensi Pare ( Momordica charantia L ) Sebagai Penurun Kadar Kolesterol Darah Metode. Jurnal Ilmiah Kesehatan Sandi Husada, 10(2), 188192. https://doi.org/10.35816/jiskh.v10i2.147

6. Muchtaridi, Yanuar, A., Megantara, S. (2018). Kimia Medisinal: Dasar Dasar Dalam Perancangan Obat. Jakarta: Prenadamedia Grup.

7. Ofli, F., Chaudhry, R., Kurillo, G., Vidal, R., \& Bajcsy, R. (2013). Berkeley MHAD: A comprehensive Multimodal Human Action Database. In IEEE (pp. 53-60). Tampa, FL: IEEE Workshop on Applications of Computer Vision (WACV). https://doi.org/DOI: 10.1109/WACV.2013.6474999

8. Putri, C. A., Yuliet, \& Khaerati, K. (2018). EFEKTIVITAS EKSTRAK DAUN KERSEN (Muntingia calabura L.) TERHADAP PENURUNAN KADAR KOLESTEROL TOTAL TIKUS PUTIH JANTAN (Rattus norvegicus L.) YANG DIINDUKSI PAKAN TINGGI LEMAK. Biocelebes, 12, 1-8.

9. Rahma, S., Natsir, R., Kabo, P., Keperawatan, I., Gorontalo, U. N., Biokimia, B., ... Trigona, M. (2014). PENGARUH ANTIOKSIDAN MADU DORSATA DAN MADU TRIGONA TERHADAP PENGHAMBATAN 
DOI : https://doi.org/10.24843/JFU.2020.v09.i03.p03

pISSN: 2301-7716; eISSN: 2622-4607

Jurnal Farmasi Udayana, Spesial Issue Desember 2020, 152-159

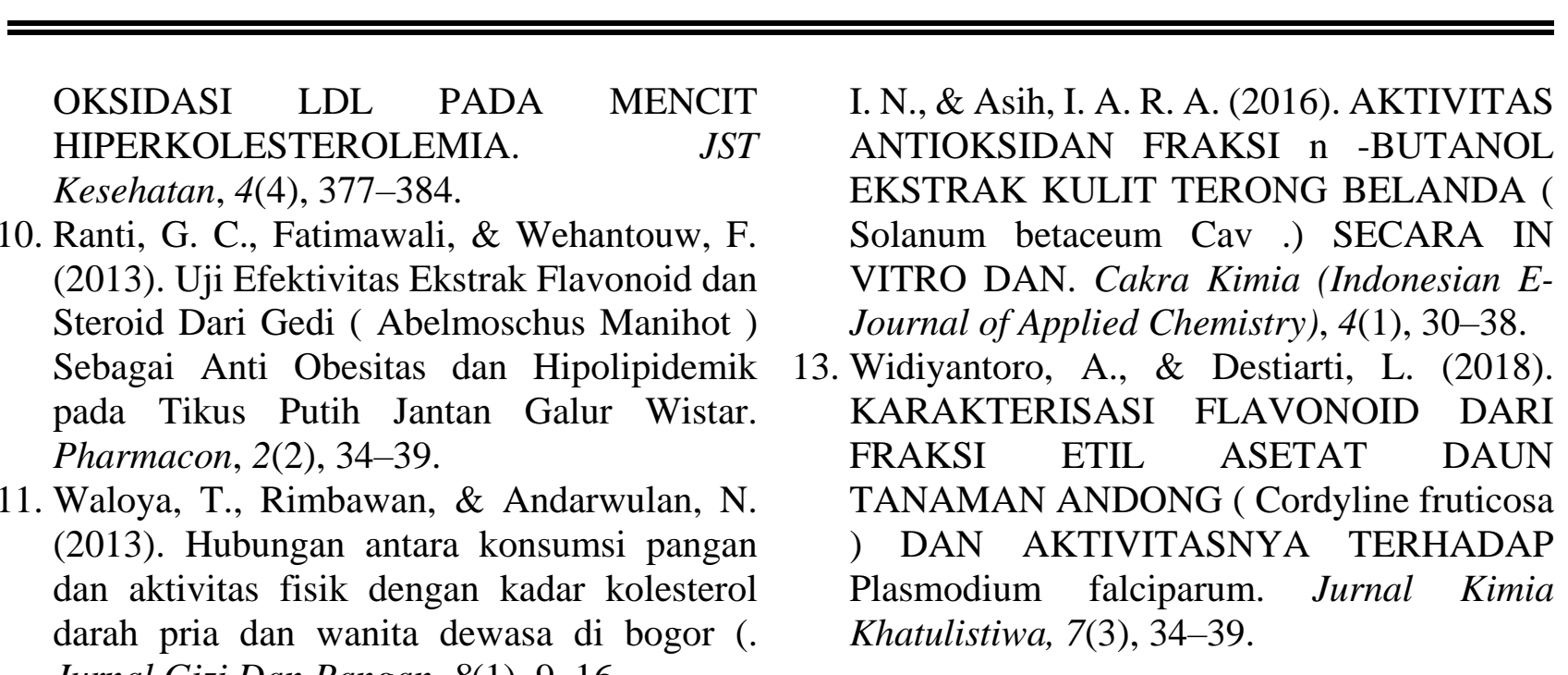

Jurnal Gizi Dan Pangan, 8(1), 9-16.

12. Widayanti, N. P., Puspawati, N. M., Suarsana,

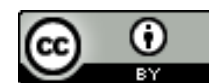

This work is licensed under a Creative Commons Attribution 4.0 International License 